\title{
Growth and production dynamics of Calanus glacialis in an arctic pelagic food web
}

\author{
D. Slagstad ${ }^{1}$, K. S. Tande ${ }^{2, *}$ \\ ${ }^{1}$ Foundation of Scientific and Industrial Research (SINTEF), Division of Automatic Control, N-7034 Trondheim, Norway \\ ${ }^{2}$ The Norwegian College of Fishery Science, University of Tromsø, Norway
}

\begin{abstract}
A production model for the herbivorous arctic copepod Calanus glacialis is presented. The model combines data on growth rates obtained from energy balance studies with population structure data gathered during the arctic productive period. A 2 yr life cycle suggests that the species is present in the plankton as 2 main year classes, thus enabling it to utilize the short annual spring bloom during both spawning and the intensive growth period from CIV to CV This pattern of life cycle should reduce the probability of food limitation during spawning and during periods of high lipid deposition as from CIV to $\mathrm{CV}$ A tentative assessment of total annual production is calculated to $8.4 \mathrm{~g} \mathrm{C} \mathrm{m}^{-2}$ with a maximum of $0.16 \mathrm{~g} \mathrm{C} \mathrm{m}^{-2} \mathrm{~d}^{-1}$ during August. P/B ratios calculated from balance experiments ranged from 0.03 to 0.05 during July. Results from sensitivity analysis are presented in order to highlight especially important ecological aspects of this species in the arctic environment.
\end{abstract}

\section{INTRODUCTION}

The herbivorous copepod Calanus glacialis is considered to have a key position in the marine food web of arctic waters of the Barents Sea (Tande et al. 1985). High abundances and a large biomass in these areas suggest a high degree of success for this species. However, the mechanisms underlying its dominant position in the arctic copepod community, which are probably related to physiology and life cycle strategy, remain largely unknown.

Available techniques for measuring zooplankton growth and production in situ are time-consuming and often unreliable. Winberg (1971) presents 2 techniques, cohort analysis and the productivity/biomass ratio method, that may be applied to zooplankton systems. The $P / B$ technique is insensitive to food availability to the zooplankters, and cohort analysis requires repeated sampling of the same population throughout the life cycle of the organisms (Boyd 1985). Recently, Huntley (1985) proposed a maximum instantaneous growth method (MIG), which assumes that the availability of food may limit growth and production of zooplankton (Conover \& Huntley 1980). He concluded that the MIG method estimated the potential growth rate of Calanus pacificus as accurately as the cohort analysis method

- Adressee for correspondence
(Huntley 1985). Estimation of productivity at lower trophic levels has also been given more comprehensive treatment through dynamic quantitative models (e.g. Steel 1976, Hofmann 1988). These models have been valuable tools for understanding the dynamics of the various components in the marine communities.

Ecological investigations on production of Calanus glacialis are being carried out within a long-term Norwegian arctic marine research program in the Barents Sea. These have concentrated on describing populations dynamics (Tande et al. 1985) and on bioenergetic studies estimating rates of anabolism and catabolism of the various life stages of the species (Båmstedt \& Tande 1985 , Tande \& Båmstedt 1985, Tande 1988a). Another series of studies has concentrated on investigating the vertical movement behaviour and seasonal variation in grazing where this species has been strongly involved (Eilertsen et al. 1989a, b, Hansen et al. 1990).

Some of the results have been incorporated into a quantative zooplankton production model, which consists of different subunits describing the population structure (size or age), and physiology of Calanus glacialis. These submodels are an integrated part of a larger plankton model for the Barents Sea which has basically been described by Slagstad (1982, 1985). The present work estimates the overall rate and the seasonal variation in the energy flow through this copepod in the arctic zooplankton community in the Barents Sea. Sen- 
sitivity analysis has also been performed in order to highlight elements of important trophodynamic aspects.

\section{FIELD DATA}

\section{Background and methods}

The population data presented in this paper were taken from different periods in the productive season in order to quantify population dynamics of Calanus glacialis. Zooplankton samples from arctic waters of the Barents Sea were collected using a plankton net (180 $\mu \mathrm{m}$ mesh) mounted on a plankton pump system. Discrete zooplankton samples were taken from 6 to 10 depths in the uppermost $100 \mathrm{~m}$ of the water column. The sampling period at each depth was set to $5 \mathrm{~min}$, equivalent to filtering $\mathrm{ca} 30 \mathrm{~m}^{3}$ of water. The water flow was measured for each sample with a TSK flow meter, monitored at the pump outlet. Further details of the system are given in Tande (1988b). Although 80 to $90 \%$ of the population of C: glacialis was found within this depth stratum during the productive season, the water masses from the bottom to $100 \mathrm{~m}$ depth were usually sampled with a WP-2 (200 $\mu \mathrm{m}$ mesh) net equipped with a closing device. Samples were fixed immediately in formalinseawater, buffered with hexamine. Timing and locations of sampling are given in Table 1.

The material was subsampled using a Lea-Wiborg plankton splitter and the total numbers of the various copepodite stages and adults was counted in 1/10 of the total plankton sample. Calanus glacialis was identified by measuring the length or the prosome (Grainger 1961, Jaschnov 1972). Copepodite stages I and II with a prosome length within 0.75 to $0.9 \mathrm{~mm}$ and 1.2 to $1.42 \mathrm{~mm}$ respectively were considered to be $C$. glacialis. The size and distribution of other copepodite stages and adults are given in Tande et al. (1985).

In situ growth rates were estimated by measuring the different anabolic and catabolic processes enabling calculation of an energy budget. Anabolism was estimated by measuring in situ food consumption of the various copepodite stages and adult females by combining gut content measurements with evacuation rates. Further details of the methods used and the rates obtained are given in Tande \& Båmstedt (1985), Eilertsen et al. (1989a) and Hansen et al. (1990). The catabolic rate of various copepodite stages and adult females was estimated by measuring respiration. All the data used in this study stem from shipboard experiments conducted on copepodite stages and adult females sampled in arctic waters or in Polar Front areas of the Barents Sea (Tande 1988a). Dry weights of copepodite stages and females were obtained from freshly caught individuals during the arctic productive season. The $\mathrm{C} / \mathrm{N}$ ratio of copepodite stages and females was not measured, but was calculated based on the stagespecific increase in $\mathrm{C} / \mathrm{N}$ ratio of the sibling species Calanus finmarchicus in Balsfjorden, northern Norway

Table 1. Calanus glacialis. Abundance estimates (ind $\mathrm{m}^{-2}$ ) of copepodite stages and adults in areas with Arctic water. Estimates for Stn 128 are given as ind. $\mathrm{m}^{-3}$. Symbols: + , is present in the sample; -, is not present in the sample; ${ }^{*}$ data from Tande et al. (1985)

\begin{tabular}{|c|c|c|c|c|c|c|c|c|c|c|}
\hline \multirow[t]{2}{*}{ Stn } & \multirow[t]{2}{*}{ Position } & \multirow{2}{*}{$\begin{array}{l}\text { Date of } \\
\text { sampling }\end{array}$} & \multicolumn{5}{|c|}{ Copepodite stages } & \multicolumn{2}{|c|}{ Aduits } & \multirow{2}{*}{$\begin{array}{l}\text { Integrated } \\
\text { depth }(\mathrm{m})\end{array}$} \\
\hline & & & I & II & III & IV & V & Females & Males & \\
\hline 43 & $\begin{array}{l}75^{\circ} 54^{\prime} \mathrm{N} \\
30^{\circ} 45^{\prime} \mathrm{E}\end{array}$ & 19 Apr 1986 & - & 5 & 38 & 39 & 156 & 311 & - & $0-100$ \\
\hline 45 & $\begin{array}{l}75^{\circ} 26^{\prime} \mathrm{N} \\
33^{\circ} 42^{\prime} \mathrm{E}\end{array}$ & 20 Apr 1986 & - & 7 & 149 & 170 & 87 & 178 & - & $10-100$ \\
\hline 128 & $\begin{array}{l}78^{\circ} 04^{\prime} \mathrm{N} \\
34^{\circ} 26^{\prime} \mathrm{E}\end{array}$ & 4 Jun 1983 & + & - & 95 & 4200 & 750 & 850 & - & $0-50$ \\
\hline 33 & $\begin{array}{l}76^{\circ} 27^{\prime} \mathrm{N} \\
34^{\circ} 13^{\prime} \mathrm{E}\end{array}$ & 30 May 1986 & 23 & 45 & 990 & 1643 & 218 & 2130 & - & $0-100$ \\
\hline $25-30$ & $\begin{array}{l}79^{\circ} 16^{\prime} \mathrm{N} \\
25^{\circ} 15^{\prime} \mathrm{E}\end{array}$ & 24-25 Jul 1984 & 51660 & 57480 & 27870 & 2963 & 1109 & 75 & - & $20-80$ \\
\hline $69-75$ & $\begin{array}{l}81^{\circ} 05^{\prime} \mathrm{N} \\
26^{\circ} 32^{\prime} \mathrm{E}\end{array}$ & $27-28$ Jul 1984 & 73665 & 60720 & 4.9274 & 1809 & 350 & - & - & $10-70$ \\
\hline $528^{\circ}$ & $\begin{array}{l}76^{\circ} 00^{\prime} \mathrm{N} \\
33^{\circ} 17^{\prime} \mathrm{E}\end{array}$ & 2 Jul 1981 & + & + & 640 & 1220 & 240 & - & - & $\begin{array}{l}\text { Surface- } \\
\text { bottom }\end{array}$ \\
\hline $575^{\circ}$ & $\begin{array}{l}76^{\circ} 53^{\prime} \mathrm{N} \\
33^{\circ} 17^{\prime} \mathrm{E}\end{array}$ & 4 Jul 1981 & + & + & 20 & 220 & 760 & 70 & - & $\begin{array}{l}\text { Surface- } \\
\text { bottom }\end{array}$ \\
\hline $995^{\circ}$ & $\begin{array}{l}78^{\circ} 10^{\prime} \mathrm{N} \\
27^{\circ} 34^{\prime} \mathrm{E}\end{array}$ & 15 Aug 1981 & + & + & 350 & 10 & 2950 & 480 & - & $\begin{array}{l}\text { Surface- } \\
\text { bottom }\end{array}$ \\
\hline $962^{\circ}$ & $\begin{array}{l}78^{\circ} 50^{\prime} \mathrm{N} \\
34^{\circ} 47^{\prime} \mathrm{E}\end{array}$ & 12 Aug 1981 & + & + & 1280 & 160 & 7920 & 800 & - & $\begin{array}{l}\text { Surface- } \\
\text { bottom }\end{array}$ \\
\hline
\end{tabular}


(Tande 1982). Resultant dry weights in carbon are given in Table 2.

\section{MODEL FORMULATION}

\section{Environmental conditions}

The structure of the plankton model developed for the Barents Sea contains submodels for zooplankton, phytoplankton, and physical transport and mixing. In the present study this 2-dimensional model (horizontal and vertical axes) simulates a seasonal succession in the physical environment and the phytoplankton community around $77^{\circ} \mathrm{N}, 30^{\circ} \mathrm{E}$ in the central part of the Barents Sea (Fig. 1). The sea is cold $\left(-1.7^{\circ} \mathrm{C}\right)$ throughout the year. More variable vertical temperature conditions prevail near the Polar Front, where slightly warmer and more salty Atlantic waters can be found. The general hydrographical conditions in this area are described in Tantiura (1959), Vowickel \& Orvig (1970) and Loeng (1979). The present simulations are performed for arctic waters with temperature and salinity data measured in 1983.

\section{The phytoplankton model}

Phytoplankton production depends on a large number of cellular characteristics together with environ-

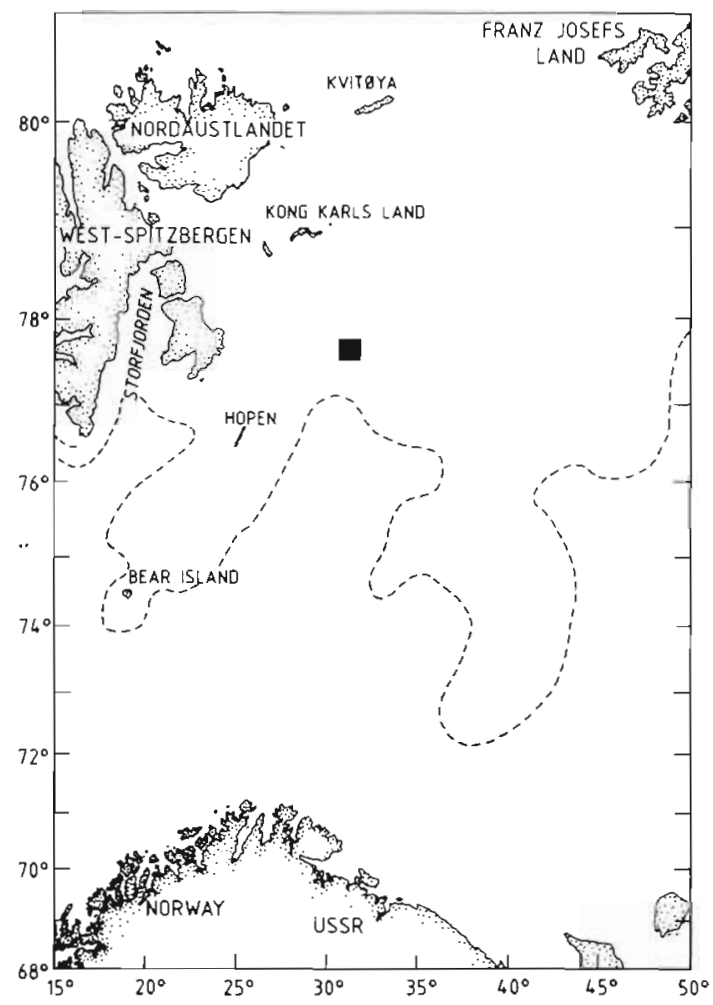

Fig. 1. The Barents Sea. Dashed line indicates average position of the Polar Front. ( $)$ Area of simulation

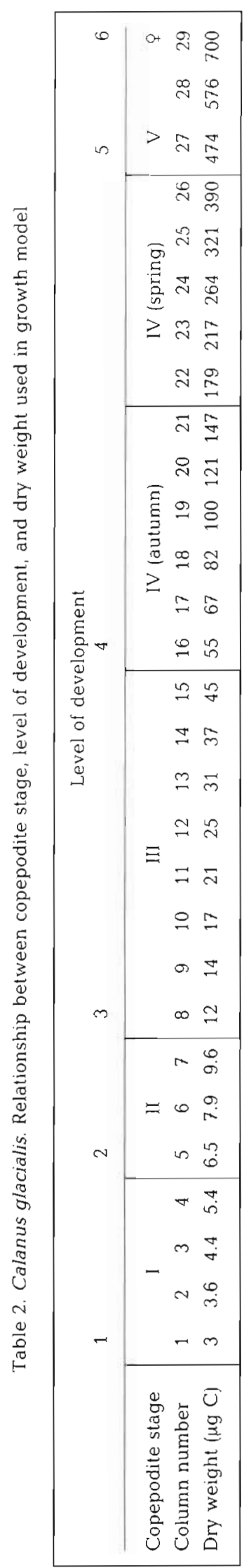


mental variables such as light, temperature and nutrient supply. The present submodel simulates primary production as a function of light nutrients (nitrogen), algal respiration, sinking rate and grazing. A detailed description of the phytoplankton model and the different parameters and values used can be found in Slagstad $(1982,1985)$.

\section{The population model}

The general structure of the population model has been simplified for Calanus glacialis compared to that given for Calanus in Slagstad (1981). In the present version of the model the population is described by a density function $\eta(t, w)$ with the following properties: Number of individuals with weight between $w_{1}$ and $w_{2}$ is

$$
\eta=\int_{w_{1}}^{w_{2}} \eta(t, w) d w
$$

where $t=$ time and $w=$ weight. The total number of individuals in the population is given by

$$
\eta=\int_{0}^{x} \eta(t, w) d w
$$

It can be shown (Himmelblau \& Bishoff 1968) that the density function $\eta(t, w)$ with these properties satisfies the partial differential equation

$$
\frac{\partial \eta}{\partial t}+\frac{\partial}{\partial w}(g \eta)=-D \eta
$$

where $g(t, w)$ and $D(t, w)=$ growth and mortality rates, respectively, for individuals of weight $w$ and at time $t$. The growth rate, g, was calculated by the physiological model.

The present population model is based on a 2 yr life cycle (Tande et al. 1985). Proportions of the different copepodite stages and adult females Calanus glacialis sampled at 3 different times in the Barents Sea (April and May 1986 and July 1984) indicate a numerical dominance of CI to CIII during summer (Fig. 2). During spring, copepodite stage IV and adult females were commonest in the population. Considering only the variation in the proportion among CIV, CV and adult females, there appeared to be a buildup of CIV relative to CV during June.

A large variation in the abundance and stage composition of Calanus glacialis was found in different regions in arctic waters of the Barents Sea (Table 1). The spawning stock during April and May was very low towards the southern boundary of the arctic water, whereas the abundance of adult females was ca 20 times higher in the same period in more true arctic water masses further north $\left(76\right.$ to $\left.78^{\circ} \mathrm{N}\right)$. Thus, data from other areas during August underline the large

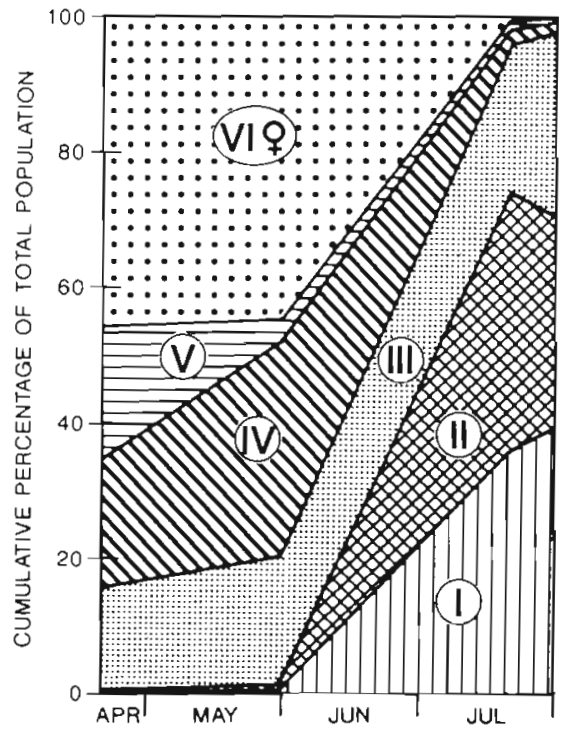

Fig. 2. Calanus glacialis. Variation in the composition of copepodite and adult stock during the productive season in Arctic waters in the Barents Sea

heterogeneity in the proportion of CIV, CV, and aduit females in the population during the productive period. Both spatial and temporal heterogeneity in the stage composition underline that conclusions concerning the population dynamics of $C$. glacialis should be made with caution.

Mortality rates are partly calculated from the physiological model (death caused by starvation) and partly from predation which is assumed to be a function dependent only on time. Abundance estimates of the various developmental stages given (see Table 1) have been adopted to scale the mortality to a correct order of magnitude for Calanus glacialis in this region of the Barents Sea. The population dynamics and the abundance estimates used in the standard run (Fig. 3) should thus be considered approximate for the area east of Svalbard.

\section{The physiological model}

The physiological model of an individual copepod is based on the principle of energy balance. The model contains 2 energetic state variables (satiation and individual energy content), which determine ingestion, growth, respiration, reproduction and vertical migration. Ingestion and vertical migration behaviour are also a function of phytoplankton concentration and light.

\section{Growth and development}

The functional relationship between weight and development relates a certain weight to a certain 
Fig. 3. Calanus glacialis. Abundances and propthe simulation period in the standard run agation of different copepodite stages during

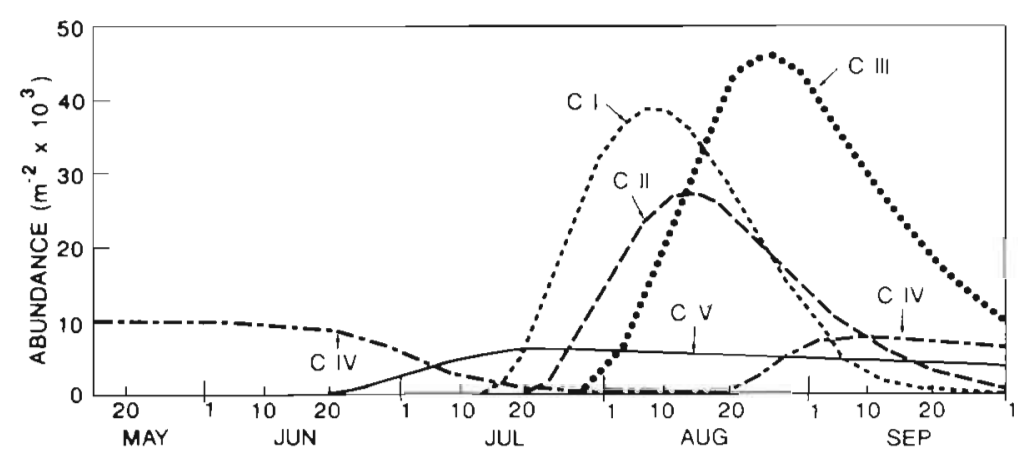

then combined with a developmental pattern suggested from a 2 yr life cycle (Tande et al. 1985). The individual dry weights of CIII to adult females underline the large variations in stage-specific dry weights among $C$. glacialis. The dry weight appears to vary by a factor of 2 among CIII to adult females. C. glacialis probably passes through 2 diapause periods during its life time, the first period as CIV's and the second as CV's. A synchronous 2 yr life cycle suggests that the population is present during the spring phytoplankton bloom as 3 main age groups: the spawning generation, recruits (nauplii) and CIV's.

\section{Grazing}

To obtain an anabolic value in the carbon budget, food consumption of Calanus glacialis was quantified using the following equation

$$
F R_{m}=F R_{0} \times w^{p} \times \exp \left(a_{t} T\right)
$$

ous copepodite stages. Copepodite stage IV was grouped into 2 size categories, the smaller representing individuals found during autumn and the larger those from the following spring.

The proposed growth curve of Calanus glacialis is constructed from a larger number of individual weight measurements from samples in Polar Front areas during the productive season. (Fig. 4). These weights were

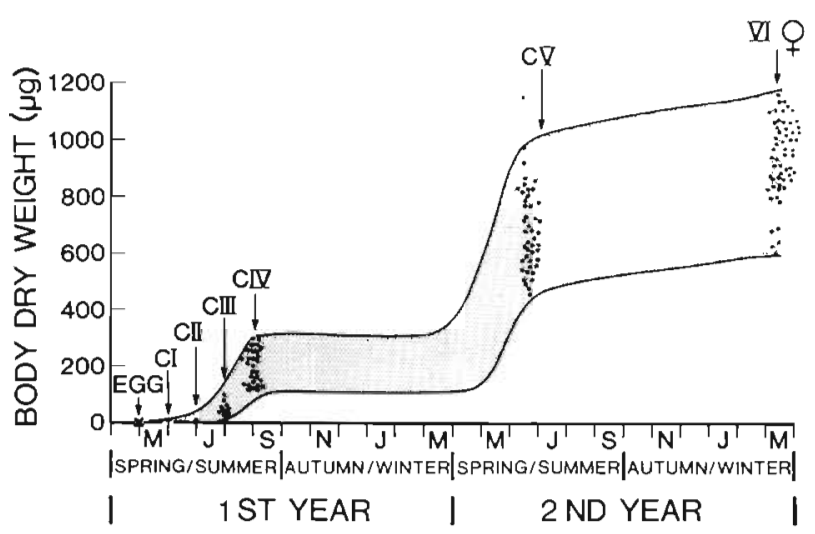

Fig. 4. Calanus glacialis. Proposed growth curve based on a biennial life cycle in Arctic waters of the Barents Sea where $\mathrm{FR}_{\mathrm{m}}=$ maximum filtering rate $\left(\mathrm{ml} \mathrm{h}^{-1}\right) ; \mathrm{FR}_{\mathrm{o}}=\mathrm{a}$ parameter which defines maximum filtering rate $(\mathrm{ml}$ $\mathrm{h}^{-1}$ ) at $0^{\circ} \mathrm{C}$ of an individual of weight $1 \mu \mathrm{g} \mathrm{C} ; \mathrm{a}_{\mathrm{t}}$ and $\mathrm{p}$ denote how the filtering rate is influenced by temperature (T) and body weight $(\mathrm{w}) . \mathrm{a}_{\mathrm{t}}$ and $\mathrm{p}$ were set to 0.17 and 0.82 according to Conover \& Huntley (1980). From Tande \& Båmstedt (1985) maximum in situ clearance rate of CV or adult female C. glacialis was calculated to be 24 and $164 \mathrm{ml} \mathrm{h}^{-1}$, respectively. By substituting these in Eq. (4), FR is calculated to be 0.7. A large variation in the calculated clearance rate was found for C. glacialis (Tande \& Båmstedt 1985, their Fig. 7), so in the present simulation $F_{0}$ was set to 0.1 . The maximum filtering rate sets an upper limit on the ingestion rate. If food is abundant, the actual filtering rate is adjusted by the level of satiation to meet energy requirements.

The assimilation efficiency was not measured for Calanus glacialis, but results obtained on CV C. hyperboreus suggest that it was high (80 to $85 \%$ ), and only influenced to a small extent by consumption rate (Tande \& Slagstad 1985). In this study the assimilation efficiency was taken as $80 \%$. 
Respiration

Respiration was measured in the various copodite stages and in adult females of Calanus glacialis to give estimates of the catabolic rate. In the physiological model this rate was divided into standard metabolism and energy cost of feeding and digestion (SDA). Although a proportionate value for these different components is difficult to obtain (see however Kiørboe et al. 1985), these sub-processes were summed to be in accordance with the overall energy loss measured through respiration rates given in Tande (1988a).

\section{Reproduction}

The rate of egg production is assumed to be proportional to the level of satiation (Slagstad 1981), which means that reproduction will be closely related to the quality of food. The parameters of the equation which predicts egg production rate given in Slagstad (1981) were chosen so that the rate of egg production agreed with reported values of this species in the Arctic (Hirche \& Bohrer 1987). When food is abundant this gives an approximate fecundity of 600 eggs per female. The specific carbon content in eggs of Calanus glacialis was $0.44 \mu \mathrm{g} \mathrm{C}$ (Hirche \& Bohrer 1987).

\section{Vertical migration model}

A model of the vertical migration of Calanus glacialis was constructed, based on available information from field data. During the spring bloom the majority of the population is present in surface waters above $50 \mathrm{~m}$ depth. A descent among the various developmental stages coincides with the culmination of the spring bloom. During the summer the population is distributed within or slightly below the maximum deep water chlorophyll layer which is usually situated between 40 and $60 \mathrm{~m}$ of depth (Eilertsen et al. 1988a, Hansen et al. 1990). CIV and CV C. glacialis tend to be found at deeper depths $(50$ to $100 \mathrm{~m}$ ) than CI to CIII during this period. The model produces a vertical structure in the population and generally places individuals in the region where the phytoplankton concentration is highest (up to $300 \mu \mathrm{g} \mathrm{Cl}^{-1}$ ). The model describes the vertical behaviour of $C$. glacialis most accurately when each individual avoids light stronger that some upper limit which is modified by the level of station. A deeper depth distribution of CIV and CV compared to the other copepodite stages during the summer and autumn is simulated by introducing age-specific responses to the upper light limit.

\section{PRODUCTION ESTIMATES}

Measured ice and temperature conditions at $77^{\circ} \mathrm{N}$ $30^{\circ} \mathrm{E}$ in spring and summer 1983 (satellite data by courtesy of the Norwegian Meteorological Institute, Norway) were taken as input values for the standard run. Total gross primary production during the simulation period was $55.7 \mathrm{~g} \mathrm{C} \mathrm{m}^{-2}$, where $47 \mathrm{~g} \mathrm{C} \mathrm{m}^{-2}$ was new production and $8.7 \mathrm{~g} \mathrm{C} \mathrm{m}^{-2}$ regenerative production (Fig. 5A). The regenerative production, which is based on the ammonium excreted from Calanus glacialis, is low compared to what is considered typical for marine systems. However, recent data from high latitude environments suggest that this proportion between new and regenerative production is of the right order of magnitude (Wassmann in press).

Production of Calanus glacialis was then calculated separately in the different age groups present, which were allowed to grow with a dynamic food supply during the simulation period (Fig. 5B). By combining production from the spawning stock and from the subsequent recruits it appears that the latter contribute most to the total production from June to August. However, the second age group (CIV and CV) contributed most to overall production during the spring bloom. Total annual production is calculated to $8.4 \mathrm{~g}$ $\mathrm{C} \mathrm{m}^{-2}$. Production rate increased from $0.09 \mathrm{~g} \mathrm{C} \mathrm{m}^{-2}$ $\mathrm{d}^{-1}$ in June to a maximum of $0.16 \mathrm{~g} \mathrm{C} \mathrm{m}^{-2} \mathrm{~d}^{-1}$ at the beginning of August. By comparing the production estimates of $C$. glacialis with the calculated primary production, it is evident that a higher proportion of the primary production is incorporated into this herbivor-
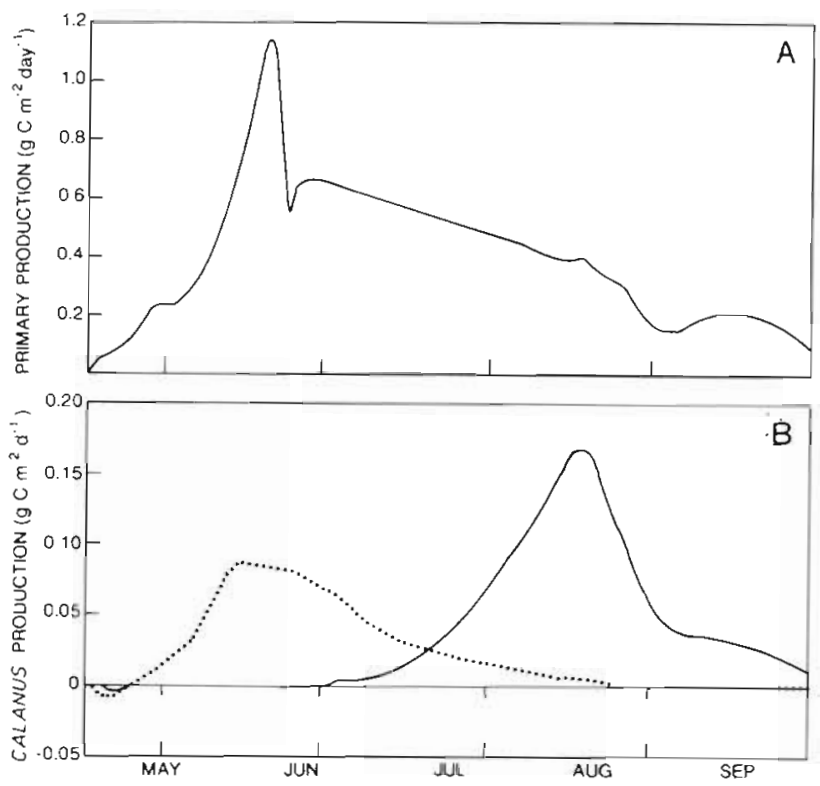

Fig. 5. Variation in (A) primary production, and (B) production of Calanus glacialis, during a simulated period of $120 \mathrm{~d}$ in arctic waters in the Barents Sea. (...) CIV to CV: (-) adult females and nauplii to CIV 
ous component during the summer period than during the spring bloom period.

\section{SENSITIVITY ANALYSIS}

The model equations given in the previous sections contain many parameters which are known with different degree of accuracy. In the following the results from the so-called standard run are compared with runs where the parameters are separately perturbated. The results from these simulations are given in Slagstad \& Tande (1989) and those results which highlight especially important trophodynamic aspects are presented in the following.

\section{Copepod feeding behaviour}

The available data describing the level of filtering rate for an individual of unit weight is quite variable. For Calanus spp. in the Canadian Arctic FR。 varied from 0.016 to $0.056 \mathrm{ml} \mathrm{h}^{-1}$ (Huntley 1981, Conover \& Huntley 1980), whereas for Calanus glacialis in the Barents Sea $F_{0}$ for an individual of weight $1 \mu \mathrm{g} \mathrm{C}$ was set to 0.1 . The flat response of production rate to filtering capacity above 0.15 (Fig. 6) is due to food limitation. High filtering capacity allows the copepods to sustain growth at lower food concentrations, but grazing cannot exceed primary production. When the filtering capacity becomes too low, the copepods are not able to sustain full growth at the concentrations that occur in the water column during the Arctic summer. Choice of this parameter will influence to a certain extent the production estimate of C. glacialis (Fig. 6). A filtering capacity $<0.056$ for this species, as suggested from the literature, appears too low in the present model. The feeding rates obtained on this species in the Barents

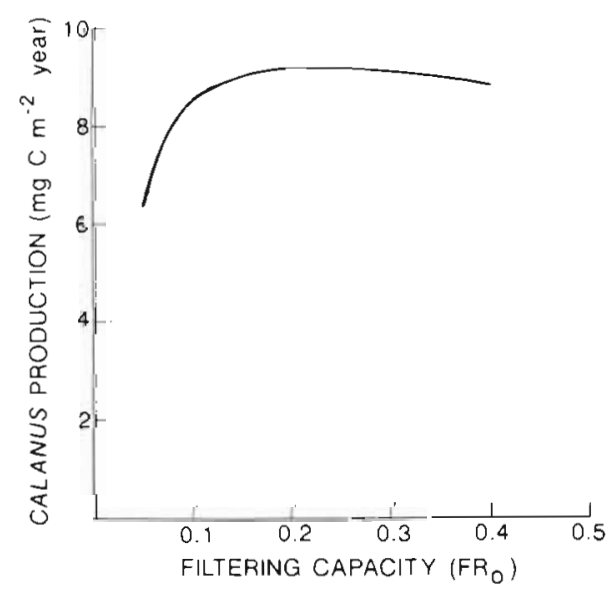

Fig. 6. Calanus glacialis. Sensitivity analysis of the impact of different values of the parameter $\mathrm{FR}_{0}$ on production
Sea give a reasonable estimate of the anabolic component in the energy balance equation, thus suggesting that a maximum filtering rate of 0.1 is probably more realistic.

\section{Ice conditions}

The amount of ice was low during spring and summer 1983 which results in anticipated high production. estimates in the standard run. During May ice cover varied between 80 and $40 \%$, whereafter it decreased to zero on 5 July. In the second simulation the amount of ice was increased during June and July by ca $50 \%$, disappearing on 10 August. This resulted in a decrease in primary production to $41 \mathrm{~g} \mathrm{C} \mathrm{m}^{-2}$. Estimated Calanus glacialis production decreased to $7.4 \mathrm{~g} \mathrm{C} \mathrm{m}^{-2}$ (ca $15 \%$ reduction). The change in environmental conditions, as suggested in the model, leads to a higher degree of overlap in the growth cycle of the 2 generations (Fig. 7A).

\section{Predation pressure}

The average mortality rate for the new generation is about $3.4 \% \mathrm{~d}^{-1}$ in the standard run. Other mortality rates may well be more realistic. In the arctic water of the Barents Sea the main predators on Calanus glacialis are chaetognaths, jelly fish and planktivorous fish. Predation pressure from these predators probably increases slowly as their population sizes increase during the summer. Increasing or decreasing the mortality rate of the recruits produced during the spring period by $50 \%$ caused a decrease of $13 \%$ and an increase of $6 \%$ in production, respectively (Fig. $7 \mathrm{~B}$ ). Observed changes in the overall production resulting from a pertubation of $50 \%$ in predation rate were small. Higher predation rates leave more phytoplankton available to those which remain, suggesting an overall compensating effect on C. glacialis production for higher mortality. An opposite effect is found during regimes with lower predation.

\section{Predation from planktivorous fish}

Another mortality strategy would prevail if capelin, during its feeding migrations, enters arctic waters from the south. Since this fish is an efficient predator on Calanus glacialis, a high mortality is to be expected as its moves through an area. To simulate this predation. pattern, it was assumed that mortality is equal to the standard run until 15 August when capelin enter the area and consume $80 \%$ of the population from copepo- 
dite stage III to adult females (Fig. $7 \mathrm{C}$ ). This results in an immediate decrease of $60 \%$ in the production rate, and the total production for the whole period is in this case reduced to $7.6 \mathrm{~g} \mathrm{C} \mathrm{m}^{-2}$. If capelin grazing starts on 1 September (Fig. 7D), the majority of the population is already in the size fraction which will be grazed. This means that a substantial reduction of the population takes place, but food availability influences production more than population size. This results in a recovery of production during September.

\section{DISCUSSION}

The present model is based on a variety of assumptions, where the pattern of life cycle and the individual growth pattern of Calanus glacialis are considered as two of the more essential components for determining production. The 2 yr life cycle which has been pro-

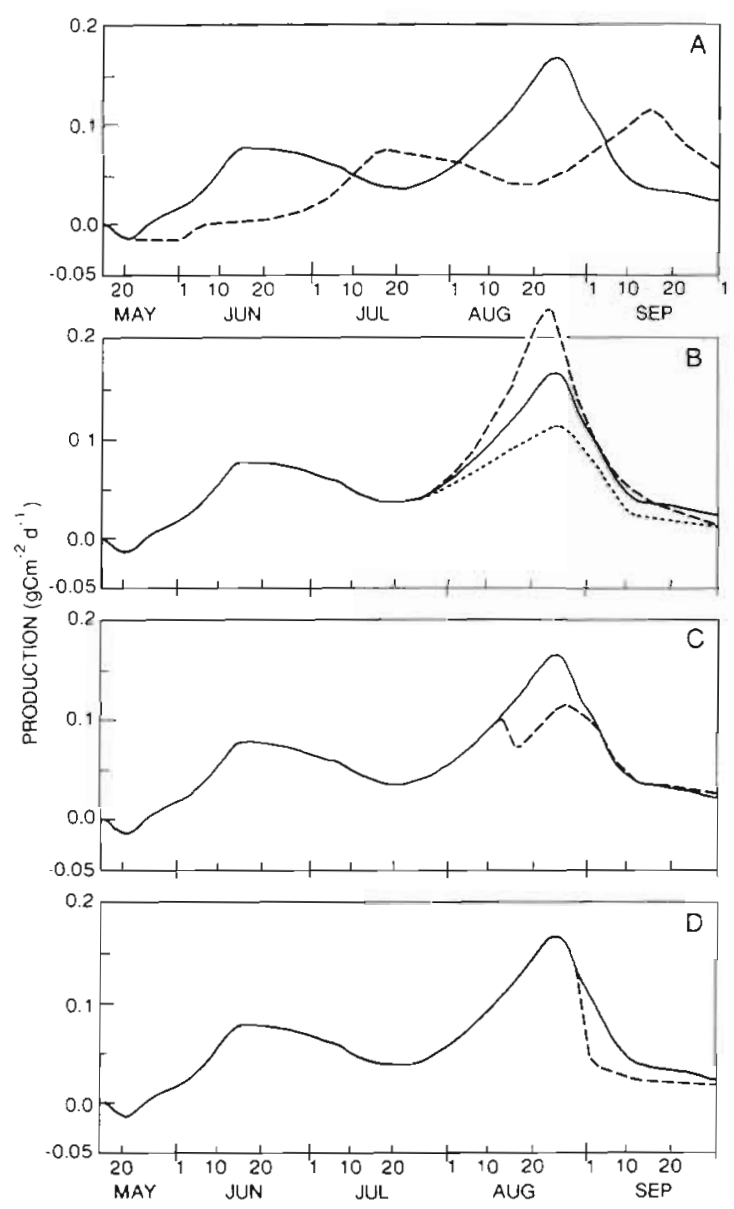

Fig. 7 Calanus glacialis. Production as a function of (A) different ice conditions (-: standard run; ---; increased amount of ice); and (B) different predation pressure (standard run; ---: $50 \%$ decrease $e_{i}$..: $50 \%$ increase). Production as a function of time when $80 \%$ of the copepodite stage III to adult is removed from the stock on (C) 15 August and (D) 1 September (- - : standard run) posed for this species in arctic waters of the Barents Sea is determined from interpretation of stage composition and ovary maturation analyses during the arctic productive period (Tande et al. 1985; see also Prygunkova 1968). The large abundances of CI to CIII at the end of July in oligotrophic waters east of Svalbard (ca 78 to $79^{\circ} \mathrm{N}$ ) appear to be a consistent feature at this time of year (Eilertsen et al. 1989a, Hansen et al. 1990). Considering that the productive period from July is expected to last for a maximum of only $2 \mathrm{mo}$, it is unlikely that this part of the population would reach $\mathrm{CV}$ during that period. However, the recruits produced in April in Polar Front areas (ca $76^{\circ} \mathrm{N}$ ) would have a better chance of reaching $\mathrm{CV}$ the same season. From rearing experiments in the laboratory it could be calculated that $C$. glacialis from the Scotian Shelf has a potential development time from egg to CIV of $112 \mathrm{~d}$ at a temperature of $-1.7^{\circ} \mathrm{C}$ (Corkett et al. 1986). Although the in situ development rate of this species in the Barents Sea appears to be on the same order of magnitude, additional laboratory experiments are essential for obtaining a conclusive generation pattern of $C$. glacialis.

A theoretical growth curve in accordance with a $2 \mathrm{yr}$ life cycle suggests that Calanus glacialis could reproduce one year and pass through the intensive growth period from CIV to CV the next year during the spring phytoplankton bloom in the Arctic. Although the present growth curve is open to discussion, a slight increase in dry weight from CV to adult females is not consistent with what is known to occur in sibling species such as C. finmarchicus (Tande 1982). Copepodite stage CV in Balsfjorden (northern Norway), which is present in the population during the period of sexual differentiation and moulting into adults in January and February, is found to be significantly larger than that present during spring in April and May (Tande 1982). Individual dry weights of CV C. glacialis have been obtained during arctic spring and early summer. These CV's, which are probably to a large extent remnants of the overwintering population of C. glacialis, should be considered analogous to the overwintering CV's in the population of $C$. finmarchicus during the spring in Balsfjorden (Tande 1982). Although the dry weight relationship between $\mathrm{CV}$ and adult females C. glacialis could be explained by a size differential moulting pattern from CV to adult, a growth period of adult females during the pre-bloom period in the spring could also explain these specific weight differences.

A large number of in situ ingestion rates have been obtained for copepodite stages and adult females Calanus glacialis in the Barents Sea (Tande \& Bamstedt 1985, Eilertsen et al. 1988a, Hansen et al. 1990). The calculated grazing rates suggest that the value of $F_{0}$ used in the present study gives reasonable estimates of 
consumption rates of various stages of C. glacialis. Reducing $\mathrm{FR}_{0}$ to the same order of magnitude (0.05) as obtained in controlled laboratory experiments for Calanus spp. from the Canadian Arctic (Huntley 1981, Conover \& Huntley 1980 ) reduces the energy intake below maintenance ratios for the copepodite stages during July and August. In situ grazing rates calculated by the gut pigment method are based on the phytoplankton concentration where the copepod was sampled. However, small-scale vertical migrations of individuals could induce error into the functional relationship between gut fullness and ambient chlorophyll concentration by changing the grazing and sampling locations of the individuals. A species with high filtering capacity would attain higher consumption rates at low phytoplankton concentrations, and hence decrease the level of critical food concentration $\left(\mathrm{P}_{\mathrm{C}}\right)$. This would tend to favour both an early egg production in the spring and a higher growth rate during the oligotrophic phase of the primary production period in the Arctic.

The primary production of ca $55 \mathrm{~g} \mathrm{C} \mathrm{m}^{-2}$ is considered a conservative estimate. From high-latitude fjords on the western coast of Svalbard, an annual primary production of 100 to $150 \mathrm{~g} \mathrm{C} \mathrm{m}^{-2}$ has been given by Eilertsen et al. (1990). In these waters the ice is considered to break up earlier in the spring and tend therefore to extend the productive period compared to the region east of Svalbard. However, model predictions with superabundant food increase the production estimate of Calanus glacialis from 8.4 to ca $12 \mathrm{~g} \mathrm{C} \mathrm{m}^{-2}$ during the simplified food web situation from May to September in arctic waters of the Barents Sea. The calculated annual production of $C$. glacialis demonstrates a bimodality in production during the productive period. The first peak, which is linked to the annual spring bloom, is followed by an increase in production at the end of the summer. This pattern of production is due to the proposed 2 yr life cycle, which enables the species to utilize the short annual spring phytoplankton bloom, both during spawning and part of the recruitment period, and during the intensive growth period from CIV to CV. A maximum in the production found in July and August demonstrates that the highest trophic efficiency is found during the oligotrophic summer period in the Arctic. A growth pattern consistent with a 2 yr life cycle should therefore reduce the probability of encountering food limitation during spawning and during periods of high lipid deposition as from CIV to CV. Later growth from CI to CIV during the Arctic summer facilitates a separation in time by its 2 main age groups with respect to resource utilization during the period of primary production.

The ice extension simulated in the sensitivity analysis is considered as an extreme situation compared to conditions in 1983 in the standard run (Midttun \&
Loeng 1987). The increase in the amount of sea ice results in only a minor reduction in the annual production of Calanus glacialis. This pattern of response is considered related to the assumptions that phytoplankton growth takes place under conditions of $80 \%$ ice cover, and that spawning and naupliar growth proceeds at low phytoplankton concentrations during June. Maximum filtering capacity is 3 times higher for a female than for a CIV which means that spawning starts before the energy requirements for maintenance can be met in the population of CIV's and CV's. An overall more protracted production cycle is consequently obtained. Indications of ice algae induced spawning in C. glacialis during prebloom conditions have been found (Bohrer \& Hirche 1987), but low egg production rates during June in the Barents Sea would favour a situation where a low proportion of the population would reach CIV before the overwintering period. Although recruiting $\mathrm{CI}$ to CIII C. glacialis are found with a certain amount of wax esters as long-term energy reservoirs (Tande \& Henderson 1988), high mortality rates among these stages during the subsequent overwintering period is likely.

Knowledge of mortality rates of a natural population is important for understanding ecological processes, but mortality is often difficult or impossible to measure (Myers \& Runge 1983). The mortality rate of $3.4 \% \mathrm{~d}^{-1}$ used for the recruiting generation of Calanus glacialis is low compared to estimates of 20 to $30 \% \mathrm{~d}^{-1}$ given for calanoid copepods from temperate waters (Matthews et al. 1978, Aksnes \& Magnesen 1983, Myers \& Runge 1983). A 2 yr life span for C glacialis, with an estimated fecundity of 600 eggs female ${ }^{-1}$ and the observed population densities of the various life stages, scales the mortality to the correct order of magnitude in the standard run. However, the large variation in abundance estimates of C. glacialis in the Barents Sea highlights the variability in population parameters such as for instance mortality. The various mortality strategies considered in this paper underline the importance for further investigations of the effect of seasonal timing between different potential predators and this copepod species in the Arctic.

The reliability of the total annual production of $8.4 \mathrm{~g}$ $\mathrm{C} \mathrm{m}^{-2}$ of Calanus glacialis with a maximum rate of $0.16 \mathrm{~g} \mathrm{C} \mathrm{m}^{-2} \mathrm{~d}^{-1}$ at the end of the Arctic summer is difficult to evaluate. Since these simulations are matched with the population densities and the energy balance budgets obtained, simulations should be considered as tentative, but of the right order of magnitude. $\mathrm{P} / \mathrm{B}$ ratios calculated from balance experiments on $C$. glacialis ranging from 0.03 to 0.05 during July are in the same order of magnitude as those found for major copepod taxa during the Antarctic productive period (Schnack et al. 1985). However, an increase in the P/B 
ratio should be expected to occur during August, due to a proportional increase of copepodite stages II and III in the population of C. glacialis. Therefore, information of the degree of flexibility within a generalised 2 yr life cycle is important in order to obtain a more detailed understanding of the productivity of this species in the Arctic

Acknowledgements. The authors acknowledge the illustrative and photographic expertise to Mrs. H. Falkseth and Mrs. G. Granaas, respectively. We are indebted to R. Barrett for correcting the English. This work was supported by the Norwegian Fisheries Research Council through the Norwegian Research Program for Marine Arctic Ecology (PRO MARE) to project 1.354 .007 and 1.401 .027

\section{LITERATURE CITED}

Aksnes, D. L., Magnesen, T (1983). Distribution, development, and production of Calanus finmarchicus (Gunnerus) in Lindåspollene, western Norway 1979. Sarsia 68: $195-208$

Boyd, C. M. (1985). Is secondary production in the Gulf of Maine limited by the availability of food? Arch. Hydrobiol. Beih. Ergeb. Limnol 21: 57-65

Bămstedt, U., Tande, K. S. (1985). Respiration and excretion rates of Calanus glacialis in arctic waters of the Barents Sea. Mar. Biol. 87: 259-266

Conover, R. J., Huntley, M. (1980). General rules of grazing in pelagic ecosystems. In: Falkowski, P. (ed.) Primary productivity in the sea. Plenum Press, New York, p. 461-485.

Corkett, C. J., McLaren, I. A., Sevigny, J.-M. (1986). The rearings of the marine calanoid copepods Calanus finmarchicus (Gunnerus). C. glacialis Jaschnow and C hyperboreus Kroyer with comment on the equiproportional rule. Syllogeus (Nat. Mus. Can.) 58: 539-546

Eilertsen, H. C., Taasen, J. P., Weslawski, J. M. (1990). Phytoplankton studies in the fjords of West Spitzbergen: physical environment and production in spring and summer. J. Plankton Res. 11 (6): 1245-1260

Eilertsen, H. C., Tande, K. S., Taasen, J. P. (1989a). Vertical distributions of primary production and grazing by Calanus glacialis (Jaschnov) and C. hyperboreus (Kroyer) in arctic waters (Barents Sea). Polar Biol. 9: 253-260

Eilertsen, H. C., Tande, K. S., Hegseth, E. N. (1989b). Potential of herbivorous copepods for regulating the spring phytoplankton bloom in the Barents Sea. Rapp. P.-v. Réun. Cnos int. Explor Mer 188: 154-163

Grainger, E. H. (1961). The copepods Calanus glacialis Jaschnov and Calanus finmarchicus (Gunnerus) in Canadian Arctic-Subarctic waters. J. Fish. Res. Bd Can. 18: 663-678

Hansen, B., Berggreen, U. C., Tande, K. S., Eilertsen, H. C. (1990). Post-bloom grazing by Calanus glacialis, C. finmarchicus and C. hyperboreus in the region of the Polar Front, Barents Sea. Mar. Biol. 104: 5-14

Himmelblau, D. M., Bischoff, K. B. (1968). Process analysis and simulation. Deterministic systems. J. Wiley \& Sons, New York

Hirche, H.-J., Bohrer, R. N. (1987). Reproduction of the arctic copepod Calanus glacialis in Fram Strait. Mar Biol 94: $11-17$

Hofmann, E. E. (1988). Plankton dynamics on the outer southwestern U.S. continental shelf. III. A coupled physicalbiological model. J. mar Res. 46: 919-946
Huntley, M. (1981). Nonselective, nonsaturated feeding by three calanid copepod species in the Labrador Sea. Limnol. Oceanogr 26: 831-842

Huntley, M. (1985). A method for estimating food-limitation and potential production of zooplankton communities. Arch. Hydrobiol. Beih. Ergeb Limnol. 21: 41-55

Jaschnov, W A. (1972). On the systematic status of Calanus glacialis, Calanus finmarchicus and Calanus helgolandicus. Crustaceana 22: 279-284

Kiørboe, T., Mohlenberg, F., Hamburger, K. (1985) Bioenergetics of the planktonic copepod Acartia tonsa: relation between feeding, egg production and respiration, and composition of specific dynamic action. Mar. Ecol. Prog. Ser. 26: 85-97

Loeng, $H$. (1979). A review of the sea ice conditions of the Barents Sea and the area west of Spitsbergen. Fisken Hav. 29-75 (in Norwegian)

Matthews, J. B. L., Hestad, L, Bakke, J. L. W. (1978). Ecological studies in Korsfjorden, western Norway. The generations and stocks of Calanus hyperboreus and C. finmarchicus in 1971-1974. Oceanologica Acta 1 277-284

Midttun, L., Loeng, H. (1987). Climatic variations in the Barents Sea. In: Loeng, $H$. (ed.) The effect of oceanographic conditions on distribution and population dynamics of commercial fish stocks in the Barents Sea. Inst. Mar Res. Bergen, p. 13-27

Myers, R. A., Runge, J. A. (1983). Predictions of seasonal natural mortality rates in a copepod population using lifehistory theory. Mar. Ecol. Prog. Ser. 11: 189-194

Prygunkova, R. V (1968). The development cycle of Calanus glacialis in the White Sea. Dokl. Akad. Nauk. SSSR 182 $1447-1450$

Schnack, S. B., SMetacek, V., Bodungen, B, v. (1985). Utilization of phytoplankton by copepods in antarctic waters during spring. In: Gray, J. S., Christiansen, M. (eds.) Marine biology of polar regions and effects of stress on marine organisms. John Wiley \& Sons, London, p. 65-81

Slagstad, D. (1981). Modeling and simulation of physiology and population dynamics of copepods. Effects of physical and biological parameters. Model. Identif. Control 2 (3): $119-162$

Slagstad, D. (1982). A model of phytoplankton growth - effect of vertical mixing and adaptation to light. Model. Identif. Control 3: 111-130

Slagstad, D. (1985). A model of phytoplankton in the marginal sea-ice zone of the Barents Sea. In: Gray, J. S., Christiansen, M. (eds.) Marine biology of polar regions and effects of stress on marine organisms. John Wiley \& Sons, London, p. $35-48$

Slagstad, D., Tande, K. S. (1989). A production model of Calanus glacialis with sensitivity analysis of variations in environmental conditions. Foundation of Scientific and Industrial Research, Trondheim (SINTEF) report no. STF48. $31 \mathrm{pp}$. (mimeo)

Steel, J. H. S. (1976). The structure of marine ecosystems Harvard University Press, Cambridge, Massachusetts

Tande, K. S. (1982). Ecological investigations on the zooplankton community of Balsfjorden, northern Norway: generation cycles, and variations in body weight and body content of carbon and nitrogen related to overwintering and reproduction in the copepod Calanus finmarchicus (Gunnerus). J. exp. mar. Biol. Ecol. 62: 129-142

Tande, K. S. (1988a). The effects of temperature on metabolic rates of different life stages of Calanus glacialis in the Barents Sea. Polar Biol. 8: 457-461

Tande, K. S. (1988b). An evaluation of factors affecting vertical distribution among recruits of Calanus finmarchicus in 
three adjacent high-latitude localities. Hydrobiologia $167 /$ 168: 115-126

Tande, K. S., Bảmstedt, U. (1985). Grazing rates of the copepods Calanus glacialis and C. finmarchicus in arctic waters of the Barents Sea. Mar. Biol. 87: 251-258

Tande, K. S., Hassel, A., Slagstad, D. (1985). Gonad maturation and possible life cycle strategies in Calanus finmarchicus and Calanus glacialis in the northwestern part of the Barents Sea. In: Gray, J. S., Christiansen, M. (eds.) Marine biology of polar regions and effects of stress on marine organisms. John Wiley \& Sons, Chichester, p. $141-155$

Tande, K. S. Henderson, R. J. (1988). Lipid composition of copepodite stages and adult females of Calanus glacialis in arctic waters of the Barents Sea. Polar Biol. 8: 333-339

This article was submitted to the editor
Tande, K. S., Slagstad, D. (1985). Assimilation efficiency in herbivorous aquatic organisms - the potential of the ratio method using ${ }^{14} \mathrm{C}$ and biogenic silica as markers. Limnol. Oceanogr 30 (5): 1093-1099

Tantiura, A. I. (1959). About the current in the Barents Sea. Trudy polyar nauchno-issled. Inst. morsk. ryb. Khoz. Okeanogr. 11. 35-53 (in Russian)

Vowickel, E., Orvig, S. (1970). The climate of the north Polar Basin. In: S. Orvig (ed.) Climates of the polar regions. Elsevier Publ., New York, p. 129-226

Wassmann, P. (in press). Relationship between primary and export production in the boreal, coastal zone of the North Atlantic. Limnol. Oceanogr.

Winberg, G. G. (1971). Methods for estimation of production of aquatic animals. Academic Press, London

Manuscript first received: August 17, 1989

Revised version accepted: March 6, 1990 